https://doi.org/10.48009/1_iis_2010_232-236

\title{
THE REASONS USERS "FAN" ORGANIZATIONAL FACEBOOK PAGES: A PILOT STUDY
}

\author{
John E. Anderson, Utah Valley University, janderson@uvu.edu \\ James McCulloch, Utah Valley University, Jim.McCulloch@uvu.edu \\ Keith Mulbery, Utah Valley University, keith.mulbery@uvu.edu
}

\begin{abstract}
Social networking application use has become ubiquitous. Facebook is the most-used social network. Facebook started as a collection of personal Facebook pages; however, organizations have also started to create Facebook pages. We conducted a pilot study of self-described reasons why Facebook participants "fan" an organizational Facebook page, generalizing to why social networking participants link themselves to organizational social network sites, to help organizations optimize their social networking activities. This will also inform follow-up studies.
\end{abstract}

Keywords: Business Use of Social Networking, Organization Pages, Facebook, Social Network Marketing

\section{INTRODUCTION}

Social networking applications have become a ubiquitous form of communication used by college students (Kryzanek, 2005). According to Compete.com, Facebook is the most used personal social network by worldwide monthly active users (Kazeniac 2009).

The mission of Facebook is to give "people the power to share and make the world more open and connected." Facebook started as a collection of personal Facebook pages, as the Facebook website states, "Millions of people use Facebook everyday[sic] to keep up with friends, upload an unlimited number of photos, share links and videos, and learn more about the people they meet." (Facebook 2010a)

\section{Business Use of Facebook}

However, Facebook has started to allow organizations to create "Official" Facebook pages using the link "Create a Page for a celebrity, band or business' (Facebook 2010b). Users can then click a button with the phrase "Become A Fan" to add the organizational page's news updates to their personal News Feed in their personal Facebook page, and show publicly to everyone that views their personal page what organizational pages they became a "fan" of (Melanson 2010).

The number of companies using Facebook as a promotional vehicle grew more than $192 \%$ last year and at the same time increased its market share by 194\% with over 300 million users (Gaudin 2009). Organizations use Facebook in a variety of ways to promote a professional agenda (Sohn 2007). There are also many ways to use Facebook for business as a marketing tool, including starting a fan page (Evans 2009).

Activity around an organizational page can have a powerful influence. For example, the Susan Kome Breast Cancer Foundation had hired two people full time for two years to gain only 135 users, which after the "Bra color as my status?" social activity exploded to 700 users in 2 hours (Shulte 2010). Some fans' Facebook pages are more popular than official organization Web sites (Liss 2010).

\section{Reasons to become a "Fan"}

A popular reason for using social networks is to get deals, freebies, and competitions (Buckley 2010). Another popular reason is showing support for a cause such as Ruper Grint fans helping find a distributor for his film (Asian 2009) and the abovementioned cancer foundation. A group of students from Mehlville High School in St. Louis used Facebook to help a homeless man get a place to live, medical care, and a part-time job (Weich 2009).

\section{PURPOSE}

To conduct an initial qualitative analysis of selfdescribed reasons why Facebook participants "fan" an organizational Facebook page, generalizing to why social networking participants link themselves to organizational social network sites, to help organizations optimize their social networking activities. This will also inform follow-up studies.

\section{RESEARCH QUESTIONS}

Why are organizations creating Facebook pages and how are they using them? A corollary question is 
why do people fan organizations Facebook pages? Knowing why people fan organization Facebook pages would allow organizations to optimize their use of social network sites. From a classical marketing perspective, organizations would use organizational Facebook pages to drive product sales and increase brand awareness. From an initial content analysis of organizational Facebook pages, organizations use coupons or other discount offers on social network sites to help increase sales. Organizations also seem to use social network sites as news feeds to inform social network participants of product news and events.

Thus our major research questions are:

1. Do Facebook participants "fan" organizational pages primarily to obtain discounts and follow news?

2. For what other reasons do Facebook participants "fan" organizational pages?

3. How can organizations use this information better optimize their social networking activities?

\section{METHOD}

The researchers collected a print-out of seven participants' organizational Facebook pages that they had become a "fan" of including an open ended answer to the question "Why did you fan this organizational Facebook page?" written next to the name of the organizational page. Subjects were also asked to write their age and number of years they have used Facebook on the print-out. The print-outs were scored and categorized by the researchers using qualitative data analysis and descriptive statistics to produce a ranking of reasons participants "fan" organizational Facebook pages.

\section{FINDINGS}

For this pilot study seven participant organizational Facebook page printouts were analyzed. The findings are described in Tables 1 and 2 and Figure 1 below.

Several items of interest may be noted:

1. The number of "fanned" organizational Facebook pages is surprisingly high at an average of 46, with 120 as a max and 11 as a minimum.

2. The number one reason for "fanning" an organizational Facebook page is to show support or self-identify with the organization.

3. For commercial pages the news was the second most cited reason to "fan" an organizational Facebook page, followed by entertainment and lastly coupons/discounts.

4. For not-for-profit pages entertainment was the second most cited reason to "fan" an organizational Facebook page, followed by news.

Table 1

\begin{tabular}{|l|l|l|l|l|l|l|l|l|l|l|}
\hline \multicolumn{7}{|c|}{ Basic Statistics for Reasons Users Fan Organizational Facebook Pages } \\
\hline & \multicolumn{3}{|c|}{ Total Pages } & \multicolumn{3}{c|}{$\begin{array}{c}\text { Commercial Pages } \\
\text { Only }\end{array}$} & \multicolumn{2}{c|}{$\begin{array}{c}\text { Not-For-Profit Pages } \\
\text { Only }\end{array}$} \\
\hline & Min & Max & Avg & Min & Max & Avg & Min & Max & Avg \\
\hline Total & 11 & 120 & 46 & 1 & 76 & 22 & 1 & 59 & 25 \\
\hline Show Support & 5 & 48 & 19 & 1 & 14 & 6 & 0 & 43 & 11 \\
\hline Entertainment & 1 & 53 & 14 & 0 & 8 & 3 & 0 & 45 & 13 \\
\hline News & 0 & 40 & 12 & 2 & 36 & 9 & 0 & 12 & 3 \\
\hline Coupon/Discount & 0 & 24 & 5 & 0 & 24 & 5 & 0 & 0 & 0 \\
\hline Don't Know & 0 & 1 & 1 & 0 & 1 & 0 & 0 & 1 & 0 \\
\hline
\end{tabular}


Table 2

\begin{tabular}{|l|l|l|l|}
\hline \multicolumn{4}{|c|}{ Reasons Users Fan Organizational Facebook Pages } \\
\hline Reason & $\begin{array}{l}\text { \% Average Total } \\
\text { Organizational Pages }\end{array}$ & $\begin{array}{l}\text { \% Average For-Profit } \\
\text { Commercial Pages }\end{array}$ & $\begin{array}{l}\text { \% Average Not-For- } \\
\text { Profit Pages }\end{array}$ \\
\hline Show Support & 54 & 48 & 47 \\
\hline Entertainment & 25 & 26 & 38 \\
\hline News & 21 & 35 & 18 \\
\hline Coupon/Discount & 9 & 15 & 0 \\
\hline Don't Know & 2 & 3 & 0 \\
\hline
\end{tabular}

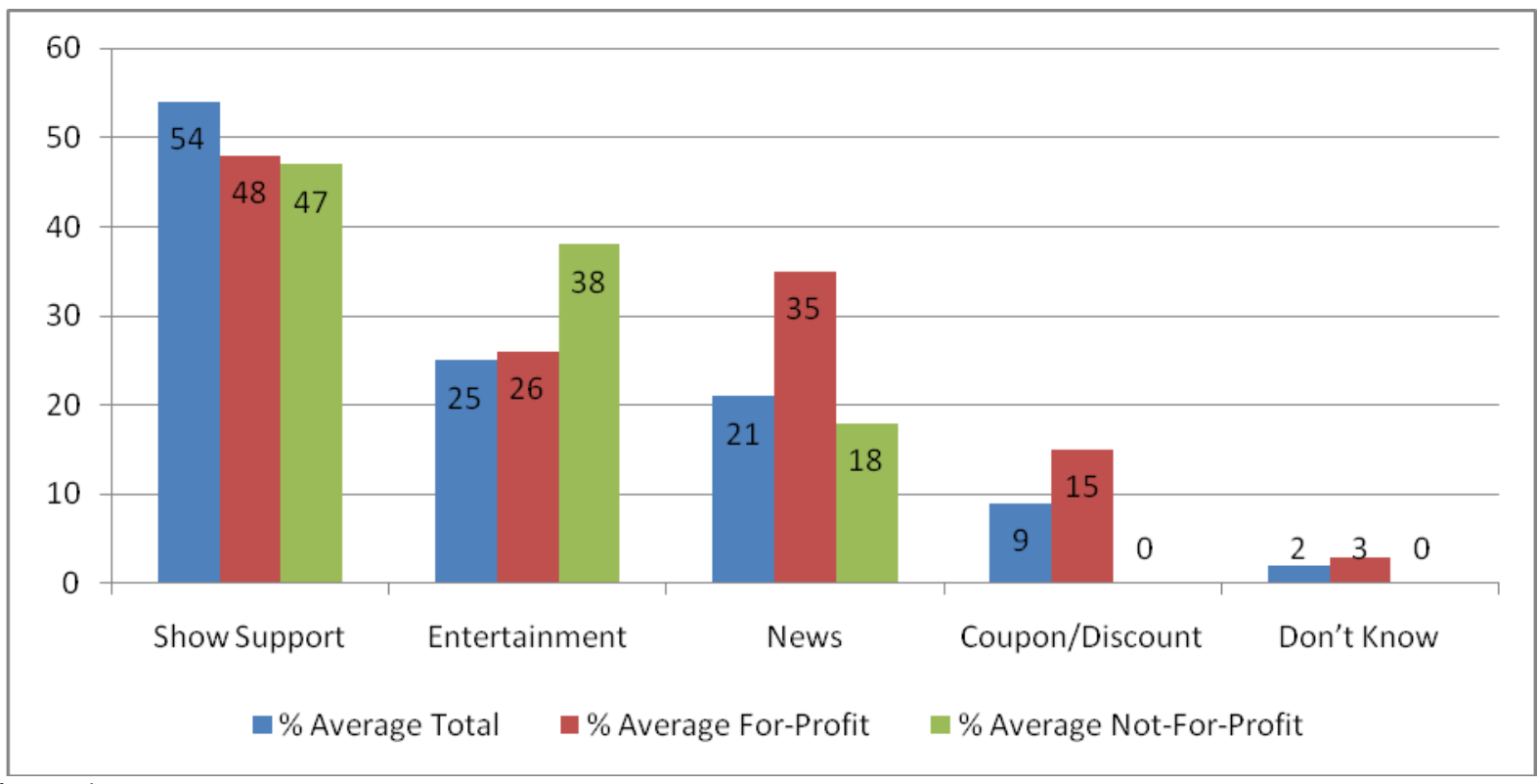

Figure 1

\section{DISCUSSION AND APPLICATION}

The idea that support/self-identification is the primary reason for "fanning" an organization Facebook page was surprising. More research needs to be done to understand this finding: Perhaps the benefit users gain from such activity is a sense of belonging. Possibly the organizational pages add a "group/commercial involvement" dimension to a user's online Facebook persona. A question for further study is: Are users really adding organizational pages to their profile because of a true desire to be affiliated with the organization or just to create a 'cool' online persona?

We expected entertainment or coupon/discount to be the most cited reason for "fanning" an organizational Facebook page; however, news and entertainment were more important reasons. If that is true, it would be best for organizations not to make a huge 
concerted effort to offer coupons, but rather focus on news releases and making their pages entertaining.

The idea the users like to review the latest organizational news is perhaps part of the age old axiom that everybody wants to be the "first to know." Maybe knowing the latest news is the mark of a true "fan". Organizations might do better to not focus on coupons as much as the periodic release of news items so that users feel like they are "in-the-know." Also, user feedback from news releases has the benefit of being almost instantaneous and essentially free public opinion without the need for R\&D.

\section{Future Questions:}

How do the findings of News and Entertainment being among the most-cited reasons for fanning organizational pages change an organization's Internet marketing strategy?

How can organizations use news to their advantage on Facebook?

Should there be different types of news feeds? If so, what types of feeds?

Why are coupons not as important as news and entertainment as reasons from fanning an organization Facebook page?

\section{CONCLUSION}

From this pilot study we conclude that:

1. Organizations would benefit by making their Facebook pages newsy and entertaining.

2. Organizations may need to continually build their brand and focus their organizational page content on their brand since selfidentification with the brand is the most important reason users "fan" organizational pages.

3. Organizations would benefit from collecting the personal information of those "fanning" their organizational page. Therefore, they should, invite potential fans to become even more associated by participating in special focus groups or member of clubs, etc.

4. After fans come to an organization's Facebook page, the organization can help keep them by offering news, entertainment, and coupons/discounts.

\section{REFERENCES}

Asian News International (2009-10-12) Ruper Grint fans' Facebook campaign helps pull distributor for new film. New Delhi

Buckley, J. (20010-01-24) Having a Twitter Account Can Save You Holiday Cash, Too. Sunday Times, London, UK, p 17

Gaudin, S. (2009-11-09) Business Use of Twitter, Facebook Exploding. Computerworld, http://www.computerworld.com/s/article/9140579/Bu siness_use_of_Twitter_Facebook_exploding Retrieved 2010-30-3

Kazeniac, Andy (2009-02-09). "Social Networks: Facebook Takes Over Top Spot, Twitter Climbs". Compete.com.

http://blog.compete.com/2009/02/09/facebookmyspace-twitter-social-network/. Retrieved 2009-0217.

Kryzanek, M. (2005) Anxieties Define Generation Y. The Boston Globe, The New York Times Company, December 8. Retrieved April 11, 2010 from

http://www.boston.com/news/local/articles/2005/12/0 8/anxieties_define_generation_y/

Facebook.com (2010a) http://www.facebook.com/facebook?ref=pf\#!/facebo $\mathrm{ok}$ ? $\mathrm{v}=$ info\&ref=pf Retreived 2010-04-13

Facebook.com (2010b) http://www.facebook.com/ Retreived 2010-004-13

Melanson, M. (2010) Do You Like Us Or Like Like Us? "Become A Fan" Changing To "Like" On Facebook.

http://www.readwriteweb.com/archives/do_you_like _us_or_like_like_us_become_a_fan_changi.php Retreived 2010-03-30

Sohn, J. (2007) 12 Ways to Use Facebook Professionally. http://webworkerdaily.com/2007/07/24/12-ways-touse-facebook-professionally/ Retreived 2010-03-30 Evans, M. (2009) 32 Ways to Use Facebook for Business. http://webworkerdaily.com/2009/07/21/32ways-to-use-facebook-for-business/ Retrieved 201003-30

Liss, S. (2010) Sports fanchises should be leading the way in social media innovation. Sun Sentinel, Fort Lauderdale, FL Feb 1, 2010 
Schulte, B. (2010, January) 'Color' fad harldy strapped for fans Facebook status plea goes viral; initiative benefits. Journal - Gazette, Ft Wayne, IN, Jan 9, 2010, p D6

Weich, S. (2009) Mehlville High grads aid their No. 1 fan Facebook group finds 'Ozzy' homeless, gives him a fresh start; Oct 23 football game is now a fundraiser. St Louis Post - Dispatch, Oct 6, 2009, p A1 